\title{
Ecological lands for conservation of vascular plant diversity in the urban environment
}

\author{
Marcin K. Dyderski ${ }^{1,2}$ • Dorota Wrońska-Pilarek ${ }^{3}$ - Andrzej M. Jagodziński ${ }^{1,2}$
}

Published online: 3 December 2016

(C) The Author(s) 2016. This article is published with open access at Springerlink.com

\begin{abstract}
Conservation of biodiversity in urban areas has become crucial to urban green area management. There are several legislative solutions for preservation of species and habitats in cities. One of them is 'ecological lands' - a lowrestrictive form of protected areas in Poland. We aimed to assess their efficiency in vascular flora biodiversity conservation in the urban environment in Poznan (W Poland; 550,000 inhabitants). We hypothesized that ecological lands which cover $<2 \%$ of the city area comprise over $50 \%$ of taxonomic diversity and over $90 \%$ of functional trait-level range of the vascular flora. Analysis of five ecological lands, which covered $1.8 \%$ of the whole city area confirmed our hypothesis. In ecological lands studied, we found 564 species of vascular plants, which is $52.9 \%$ of the whole city flora. These species belonged to 23 of 29 phytosociological classes represented in the whole city (73.9\%). Functional trait distributions in ecological lands studied comprised from 95.8 to $100 \%$ of trait distributions in the flora of the whole city. Ecological lands seem to be a good way for conservation of biodiversity in urban areas. The legislative simplicity and low restrictiveness for both land management and recreational utility make ecological lands a much easier form of nature conservation which may be adapted to other cities for more efficient biodiversity management.
\end{abstract}

Andrzej M. Jagodziński

amj@man.poznan.pl

1 Institute of Dendrology, Polish Academy of Sciences, Parkowa 5, 62-035 Kórnik, Poland

2 Faculty of Forestry, Department of Game Management and Forest Protection, Poznań University of Life Sciences, Wojska Polskiego 71c, 60-625 Poznań, Poland

3 Faculty of Forestry, Department of Forest Botany, Poznań University of Life Sciences, Wojska Polskiego 71d, 60-625 Poznań, Poland
Keywords Biodiversity conservation · Functional traits Urban flora · Urban green areas

\section{Introduction}

Urban areas are one of the land cover types most transformed by human activity. Due to land-use changes, which cause habitat fragmentation, loss and degradation of natural and semi-natural habitats, emergence of new, urban habitats, lowering the groundwater table level, increased levels of nutrients, $\mathrm{pH}$, temperature, pollution and disturbance, cities are unfavorable habitats for plant existence (Kowarik 2011). However, some groups of plant species are more threatened in urban environments than others, especially those with narrow ecological niches, associated with more-natural habitats, such as acidophilus forests, meadows or wetlands (Jackowiak 1990; Jackowiak 1993; Jackowiak 1995; Chocholoušková and Pyšek 2003; DeCandido 2004; Knapp et al. 2010). On the other hand, disturbances connected with human settlement facilitate encroachment of alien plant species, along with increased chances of naturalization in urban areas (Chocholoušková and Pyšek 2003; Knapp et al. 2010; Jarošík et al. 2011b; Kowarik 2011; Kowarik et al. 2013; Dyderski et al. 2015a; Dyderski and Jagodziński 2016). Urbanization is claimed to be one of the most important threats (together with alien species invasions, which is often associated with urbanization) for more than half of all species listed by the U.S. Endangered Species Act (Czech et al. 2000; Miller and Hobbs 2002).

Extinction of native, specialized species and expansion of cosmopolitan alien species, usually with broad ecological niches, lead to biotic homogenization - convergence of floras of more and more distant regions. This process results in losses of species diversity at regional and continental scales 
(Olden et al. 2004; McKinney 2006). This process was noted not only in floras, but also in faunas of urban areas (Horsák et al. 2013; Aronson et al. 2014). In cities, biotic homogenization goes faster than in other ecosystems, thus urban biotas are the most threatened by losses of distinguishing elements, i.e. local rare and endangered species (McKinney 2006).

The high rate of biotic homogenization in urban areas indicates a need for biodiversity conservation, even in habitats strongly transformed by humans. There is an especially high need for conservation of not only rare and endangered species, but also those which are common in natural and near-natural habitats. This need was recognized quite recently, as earlier most scientists and conservation practitioners had thought that there was no point in conservation efforts for urban and suburban areas so highly transformed by human activity (Miller and Hobbs 2002). The role of urban forests and green areas in maintaining species diversity of plants in cities is crucial (Clark et al. 1997; Alvey 2006; McPherson 2006; Dearborn and Kark 2010). Thus, it is essential to introduce nature conservation in urban green areas, to preserve the regional species pool.

There are different ways of nature conservation in urban areas. The easiest is creating nature reserves - a regime with relatively small areas with high level of restrictions on visitation and use by the public. This form of nature conservation is used, for example, in Prague (Jarošík et al. 2011a; Jarošík et al. 2011b), Warsaw (Solińska-Górnicka and Symonides 1990; Obidziński and Symonides 2000), Budapest (Samu and Szinetár 2000) and in peri-urban areas of Zurich (Seeland et al. 2002). However, there is difficulty in creating traditional, high-restrictive forms of nature conservation in highly-populated urban areas, where recreational areas are needed (Niemelä 1999; Seeland et al. 2002; Jaszczak and Wajchman 2014).

One of the legislative solutions to conserve biodiversity is ecological lands. In Polish law, this form of nature conservation is a low-restrictive type of nature conservation. According to the Nature Conservation Act (Ustawa $\mathrm{z}$ dnia 16 kwietnia 2004 r. o ochronie przyrody 2004): 'ecological lands are worthy of protection remains of ecosystems, with significant contribution to biodiversity conservation - natural reservoirs, small ponds, clumps of trees and shrubs, wetlands, peat bogs, dunes, wasteland vegetation, oxbow lakes, rocky outcrops, slopes, gravels, natural habitats according to Natura 2000 programme and habitats of rare or protected by law plants, animals and fungi, their refuges and reproduction sites or sites of temporary occurrence'. Compared to largearea forms of nature conservation, ecological lands are relatively small - an average nature reserve area in Poland is $112 \mathrm{ha}$, and an average ecological land is $7.13 \mathrm{ha}$ (Environment Protection 2014). Due to the simplicity of creation, in Poland in 2013 there were 7090 ecological lands, as compared to only 1480 nature reserves (Environment Protection 2014). Legislative simplicity is that ecological lands are created by the municipal council, as opposed to nature reserves, which are created by the regional director of environment protection, which is a regional public institution responsible for nature conservation in Poland. Moreover, nature reserves require conservation plans based on biodiversity investigation, which are not required for ecological lands (Ustawa z dnia 16 kwietnia 2004 r. o ochronie przyrody 2004).

Ecological lands do not have an equivalent classification in IUCN forms of protected areas (Dudley 2008), due to small areas (<100 ha). However, most nature reserves in Poland also cannot be classified by IUCN due to small area. Due to low number of restrictions and usually lack of active conservation, ecological lands may be analogous to the 6th IUCN category protected areas with sustainable use of natural resources and due to conservation objectives, to protect habitats and ecosystems and to provide people regular contact with nature. Low number of restrictions in ecological lands means that people are allowed to walk beside paths and they are allowed to harvest plants and fungi, while they are not allowed to do so in nature reserves. Alternatively, it may be analogous to the 4th IUCN category - habitat/species management areas, which seems to be more suitable, as the 4th category also allows areas which protect fragments of ecosystems. Due to fewer restrictions, in comparison with nature reserves, ecological lands seem to be an efficient way of biodiversity conservation in urban areas, as they allow for activities of urban residents. This compromise helps to avoid conflicts connected with more restrictive forms of nature conservation.

The aim of this study is to evaluate the proportion of taxonomic and functional flora diversity preserved by ecological lands, to assess the usefulness of this form of nature conservation in the urban environment of Poznań city (W Poland). As it was reported by Jackowiak (2011), these objects have high conservation value within the city, and we would like to quantify their biodiversity conservation capacity using the background of the biodiversity of the whole city flora. We hypothesized that three ecological lands, which comprise $<2 \%$ of city area, may host over $50 \%$ of taxonomic and over $90 \%$ of the functional traits range of vascular plants.

\section{Materials and methods}

\section{Study area}

Poznań is a city in Western Poland $\left(52^{\circ} 24^{\prime} \mathrm{N} ; 16^{\circ} 57^{\prime} \mathrm{E}\right)$, with a population of 550,700 inhabitants (Statistical Yearbook of Poznań city 2013). The climate of Poznań is transitional between oceanic and continental. Based on long term (19512010; Statistical Yearbook of Poznań city 2013) meteorological measurements, mean annual temperature was $8.4{ }^{\circ} \mathrm{C}$ and mean annual precipitation - $521 \mathrm{~mm}$. Mean length of 
vegetation season (considered as number of days with mean daily temperature $>5^{\circ} \mathrm{C}$ ) in $1951-2006$ was 225 days (Żmudzka 2012).

Poznan is located on an upland plain moraine cut by the Ravined Warta River Valley and valleys of its tributaries. A small part of the city is occupied by moraine hills and outwash plains (Jackowiak 1993; Jackowiak 2011). In Poznań, built-up areas cover $41 \%$ of city area, arable lands $-22 \%$, urban green areas $-13 \%$ and forests $-14 \%$ (Jackowiak 2011). Potential natural vegetation types are most frequently poor variants of forests with Quercus robur, Carpinus betulus and Tilia cordata (Galio sylvatici-Carpinetum betuli), on sand plains, coniferous forests with Pinus sylvestris (Leucobryo-Pinetum) or mixed Quercus robur-Pinus sylvestris forests (Querco roboris-Pinetum), and in river valleys - riparian forests with Salix spp. (Salicetum albae), Populus spp. (Populetum albae), Ulmus spp. and Quercus robur (Querco-Ulmetum minoris) and with Alnus glutinosa and Fraxinus excelsior (FraxinoAlnetum) (Wojterski et al. 1982; Jackowiak 2011). Vascular flora of Poznań in the period from 1828 to 1990 was 1299 species, including ephemerophytes (species occurring only for a short period of time) and extinct species (Jackowiak 1990; Jackowiak 2011). Native plant species comprise $69.4 \%$ of Poznań flora, whereas alien species (both archaeophytes and neophytes) - 30.6\% (Jackowiak 2011).

When our studies on role of ecological lands in biodiversity conservation started (in 2012), in Poznan there were six ecological lands: 'Bogdanka I', 'Bogdanka II', 'Strzeszyn', 'Dębina I', 'Dębina II' and 'Traszki Ratajskie' (Fig. 1, Table 1). The last one was not taken into account during our studies, due to small area (4 ha) and a different conservation purpose (conservation of amphibians), while the others were created for plant cover conservation. Chosen ecological lands are areas with the highest conservation value within the city (Przyroda miasta Poznania 2009). Their conservation value may be compared with two nature reserves, however there are no published data about the flora of the two nature reserves, and thus they cannot be compared with ecological lands. Due to small area of 'Bogdanka II' and 'Dębina II' (7.3 and 31.1 ha, respectively), we treated 'Bogdanka I' and 'Bogdanka II' as one object 'Bogdanka', as well as 'Dębina I' and 'Dębina II' as 'Dębina' in discussion, however in analyses we pooled all ecological lands together (Fig. 1, Table 1). Vegetation of the lands studied is dominated by forests, wetlands and meadows, however there are minor patches of grasslands, ruderal sites connected with roads and industrial wastelands, arable lands, gardens and shrubs.

\section{Methods}

For the assessment of taxonomic diversity and distributions of functional traits of ecological lands vascular flora, we compared the total known city flora of Poznań (Jackowiak 1990; Jackowiak 2011) with flora of three ecological lands in Poznań (Dyderski et al. 2014a; Dyderski and WrońskaPilarek 2015a, b). We chose six ecological lands from ca. 20 which were established in 1990s and were later abolished, due to law changes (Dyderski and Jagodziński 2014; Dyderski et al. 2014b). These six ecological lands were reestablished in 2012 and represent the highest conservation values among the others (Przyroda miasta Poznania 2009). Because the flora of Poznań (Jackowiak 1990) also contains species which occurred historically but are now extinct, or flora not established (ephemerophytes), we excluded these species which had any
Fig. 1 Locality of ecological lands studied within the borders of Poznań city a and borders of ecological lands $\mathbf{b}$ and $\mathbf{c}$

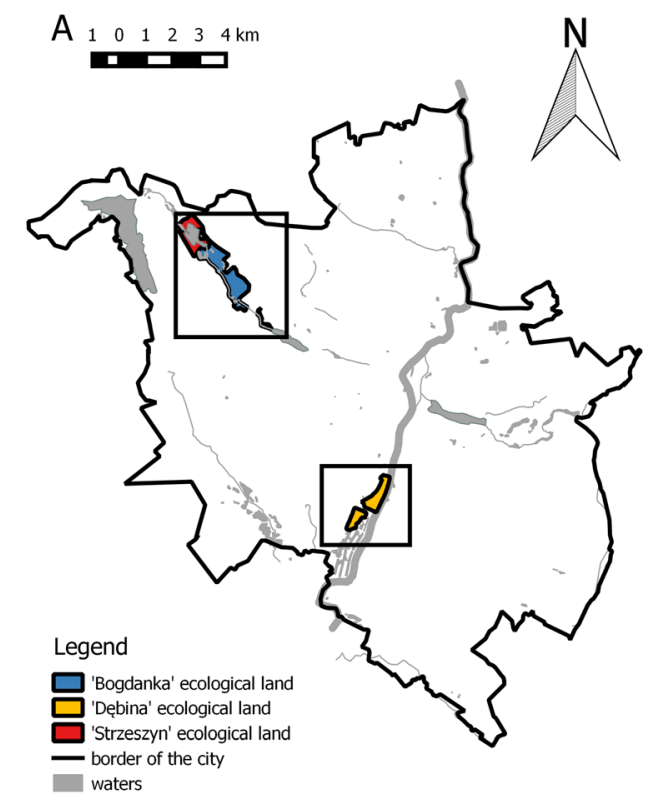

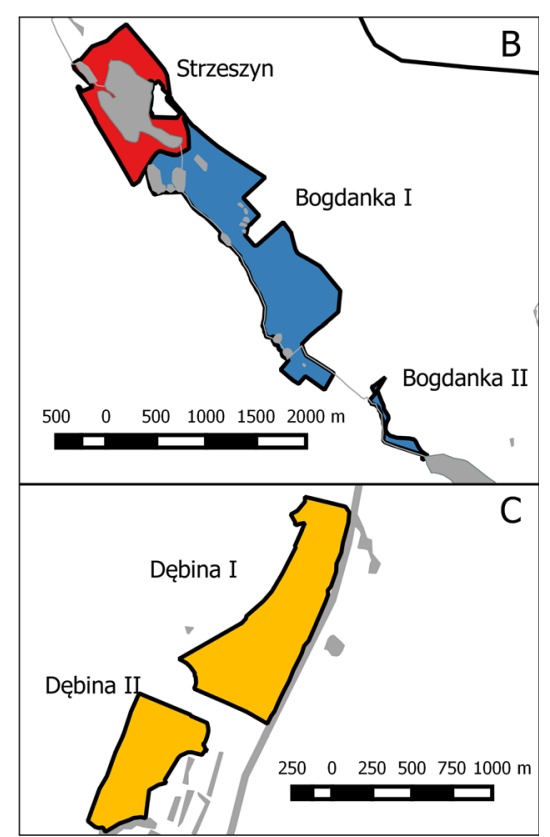


Table 1 Overview of the ecological lands studied in Poznan

\begin{tabular}{|c|c|c|c|c|c|}
\hline Name & Area & Locality & Main aim of conservation & $\begin{array}{l}\text { Vascular plants } \\
\text { species richness }\end{array}$ & References \\
\hline Bogdanka & $\begin{array}{l}\text { 'Bogdanka I' } 151.45 \text { ha } \\
\text { 'Bogdanka II' } 7.63 \text { ha }\end{array}$ & $\begin{array}{l}52.4490439^{\circ} \mathrm{N} \\
16.8407992^{\circ} \mathrm{E}\end{array}$ & $\begin{array}{l}\text { Riparian forests and fens, } \\
\text { oak-hornbeam forests, } \\
\text { wet meadows }\end{array}$ & $445(280)$ & $\begin{array}{l}\text { Wrońska-Pilarek (2010), } \\
\text { Dyderski et al. (2014a, b, 2015b) }\end{array}$ \\
\hline Dębina & $\begin{array}{l}\text { 'Dębina I' } 53.57 \text { ha } \\
\text { 'Dębina II' } 31.06 \text { ha }\end{array}$ & $\begin{array}{l}52.3637767^{\circ} \mathrm{N} \\
16.9299471^{\circ} \mathrm{E}\end{array}$ & $\begin{array}{l}\text { Toposequence of riparian } \\
\text { forests, ponds and } \\
\text { oak-hornbeam forests }\end{array}$ & $371(438)$ & $\begin{array}{l}\text { Wrońska-Pilarek and Stasik (2003), } \\
\text { Dyderski and Jagodziński (2014), } \\
\text { Dyderski and Wrońska-Pilarek (2015a) }\end{array}$ \\
\hline Strzeszyn & $\begin{array}{l}94.48 \text { ha } \\
\quad \text { (including } 34.9 \\
\text { ha of lake) }\end{array}$ & $\begin{array}{l}52.4626909^{\circ} \mathrm{N} \\
16.8226828^{\circ} \mathrm{E}\end{array}$ & $\begin{array}{l}\text { Riparian and oak-hornbeam } \\
\text { forests, alder carrs, degraded } \\
\text { mesotrophic lake, fens }\end{array}$ & $322(341)$ & $\begin{array}{l}\text { Wrońska-Pilarek (2008), } \\
\text { Dyderski et al. (2015b), } \\
\text { Dyderski and Wrońska-Pilarek (2015b) }\end{array}$ \\
\hline
\end{tabular}

${ }^{1}$ total species richness of studied object and (in parentheses) species richness per $1 \mathrm{~km}^{2}$

present locality in Jackowiak's atlas (Jackowiak 1993). We also added to this list species found in ecological lands, but not recorded by Jackowiak (1990), to compile an up-to-date flora of Poznań. Thus, we excluded 22 extinct archeophytes, four neophytes, 132 native species and 129 ephemerophytes. We also included 54 new species in this data set, including 50 species not recorded previously and 4 species which were not distinguished previously (Achillea pannonica, Betula obscura, Cardamine palustris and Dactylis aschersoniana). After this revision, 1066 species were listed as the flora of Poznan. One may be concerned that 30 years of difference between datasets in conditions of dynamic changes (e.g. Dyderski et al. 2015a) may undermine the analyzes. However, our aim is not a detailed analysis of current flora, but the comparison of ecological lands to the background of the whole city flora. Unfortunately, after Jackowiak's (1990, 1993) comprehensive study, no additional compilations of the city's flora were prepared. We compiled a database of species functional and synecological traits. In the case of species which were formerly distinguished as separate species but were merged in the database, e.g. as subspecies, we joined traits for both species, e.g. for Cannabis sativa and C. ruderalis we applied traits of C. sativa (also for Polygala comosa and P. oxyptera, Cardamine palustris and $C$. pratensis, Papaver rhoeas and P. strigosum). For all species present in ecological lands and in the flora of Poznań we prepared a database of ecological traits (Table 2). Trait completeness varied from 46.0 to $94.7 \%$, and only in the cases of 13 species (mainly alien, ornamental plants) data for all traits were unavailable. Low trait completeness for Ellenberg's ecological indicator values resulted from a high number of species with wider ecological amplitudes in the considered factor, marked as ' $x$ ' by Ellenberg and Leuschner (2010), which were treated by us as lack of data (NA), as this cannot be used as a level of an ordered factor trait. We are aware that Ellenberg's ecological indicator values have been criticized, e.g. that their responses do not differ from random assignment or for their lower performance in human-disturbed areas (Dzwonko
2001; Diekmann 2003; Zelený and Schaffers 2012). However, due to numerous confirmed correlations with instrumental measurements of indicated parameters, indicator values are widely used for various ecological analyzes (e.g. Schaffers and Sýkora 2000; Dzwonko 2001; Diekmann 2003; Godefroid and Koedam 2003; Zerbe and Wirth 2006; Mölder and Schneider 2011; Woziwoda and Kopeć 2014; Halarewicz and Żołnierz 2014). Plant nomenclature follows the checklist of Mirek et al. (2003).

We assessed species diversity at three levels: taxonomical, phytosociological and the level of functional traits range, which is not a strict measure of functional diversity, but shows the diversity of functional plant types. At the taxonomical level we compared the number of species, genera and families in the study area and in the whole city. At the phytosociological level we compared share of phytosociological classes (attachment of species to the groups of plant communities, according to Ratyńska et al. (2010), and representation of classes in both floras. At the functional traits level we compared the spectrum of functional traits (Table 2) in floras of both city and ecological lands. In cases of ordinal and numeric factors, we compared the ranges and distributions of traits studied between the whole city and ecological lands. In cases of categorical traits, we compared number of categories and proportion of each category. As most of the categorical traits were not exclusive (i.e. each species could have several levels, e.g. in cases of life form species may be classified as both geophyte and hemicryptophyte), categorical traits were not taken into account in calculating distributions and quantiles of functional traits. In cases of ordinal traits (Ellenberg's ecological indicator values), we calculated only range of traits represented in ecological lands studied, as a fraction of range of traits in the whole city. In cases of numeric traits, we compared the share of each trait as range of quantiles of the distribution of the trait in the whole city flora. We applied this quantile-approach, due to non-normal, tailed distributions of traits. All analyses and data visualizations were conducted in $\mathrm{R}$ software (R Core Team 2015). 
Table 2 Overview of the functional traits studied

\begin{tabular}{|c|c|c|c|c|c|}
\hline Trait & Ecological significance & Trait type & Values & Completeness $(\%)$ & Source \\
\hline Light & Response to light availability & ordinal & $1-9$ & 79.9 & Ellenberg and Leuschner (2010) \\
\hline Temperature & Response to temperature & ordinal & $1-9$ & 49.7 & Ellenberg and Leuschner (2010) \\
\hline Continentality & Response to climate continentality & ordinal & $1-9$ & 61.8 & Ellenberg and Leuschner (2010) \\
\hline Moisture & Response to groundwater table level & ordinal & $1-12$ & 71.0 & Ellenberg and Leuschner (2010) \\
\hline Soil reaction & Response to soil $\mathrm{pH}$ & ordinal & $1-9$ & 46.0 & Ellenberg and Leuschner (2010) \\
\hline Soil fertility & Response to soil nitrogen content & ordinal & $1-9$ & 68.8 & Ellenberg and Leuschner (2010) \\
\hline Canopy height & Competitive ability & numeric & $\mathrm{m}$ & 84.0 & LEDA (Kleyer et al. 2008) \\
\hline Dispersal mode & Dispersal, establishment & categorical & 18 categories & 94.7 & LEDA (Kleyer et al. 2008) \\
\hline $\begin{array}{l}\text { Leaf distribution along } \\
\text { the stem, }\end{array}$ & Competitive ability & categorical & 5 categories & 90.1 & LEDA (Kleyer et al. 2008) \\
\hline Leaf dry matter content & $\begin{array}{l}\text { Competitive ability, growth rate, } \\
\text { stress tolerance }\end{array}$ & numeric & $\mathrm{mg} \mathrm{g}^{-1}$ & 70.1 & LEDA (Kleyer et al. 2008) \\
\hline Leaf mass & $\begin{array}{l}\text { Competitive ability, growth rate, } \\
\text { stress tolerance }\end{array}$ & numeric & $\mathrm{mg}$ & 64.1 & LEDA (Kleyer et al. 2008) \\
\hline Leaf size & $\begin{array}{l}\text { Competitive ability, growth rate, } \\
\text { stress tolerance }\end{array}$ & numeric & $\mathrm{mm}^{2}$ & 69.0 & LEDA (Kleyer et al. 2008) \\
\hline Specific leaf area & $\begin{array}{l}\text { Competitive ability, growth rate, } \\
\text { stress tolerance }\end{array}$ & numeric & $\mathrm{mm}^{2} \mathrm{mg}^{-1}$ & 73.6 & LEDA (Kleyer et al. 2008) \\
\hline Plant life form & $\begin{array}{l}\text { Response to disturbance, } \\
\text { establishment, invasiveness }\end{array}$ & categorical & 7 categories & 71.8 & LEDA (Kleyer et al. 2008) \\
\hline Seed weight & Dispersal, establishment & numeric & $\mathrm{mg}$ & 76.7 & LEDA (Kleyer et al. 2008) \\
\hline Seed number per shoot & $\begin{array}{l}\text { Response to disturbance, } \\
\text { establishment, dispersal }\end{array}$ & numeric & number of seeds & 66.1 & LEDA (Kleyer et al. 2008) \\
\hline $\begin{array}{l}\text { Life strategy } \\
\quad(\text { Grime 1979) }\end{array}$ & $\begin{array}{l}\text { Competitive ability, stress tolerance, } \\
\text { response to disturbance }\end{array}$ & categorical & 7 categories & 88.9 & BiolFlor (Klotz et al. 2002) \\
\hline
\end{tabular}

\section{Results}

\section{Taxonomical diversity}

In the ecological lands 564 species of vascular plants were found. This number comprises $52.9 \%$ of the flora of the city. It is also $43.4 \%$ of total flora (including ephemerophytes and extinct species) of the city. Flora of ecological lands represented 295 genera and 91 families, which is $62.1 \%$ of 475 genera and $72.8 \%$ of families found in the whole city. In the ecological lands 130 species were alien (including 42 aracheophytes and 88 neophytes), which comprised $23.0 \%$ of the flora, in comparison with $30.6 \%$ in the whole flora of Poznan (102 archaeophytes and 139 neophytes).

\section{Phytosociological diversity}

In the ecological lands we found species representing 23 phytosociological classes, which comprises $79.3 \%$ of species representing 29 phytosociological classes in the whole city (Fig. 2). In the ecological lands we did not find species from Ammophiletea (sand dunes), Asplenietea trichomanis (rocks and walls), Isoëto-Litorelletea (oligotrophic and dystrophic lakes, astatic ponds), Juncetea maritimi (salt meadows), Oxycocco-Sphagnetea (raised bogs) and Thlaspietea rotundifolii (mountain rocky screes), which in the whole-city flora were represented by one to five species. The most frequent, both in the whole city and in ecological lands, were species not belonging to any class (respectively 20.9 and $19.7 \%$ of flora). In the ecological lands there were higher shares of species typical for meadows (MolinioArrhenatheretea, $16.3 \%$, while the whole city had $11.9 \%$ ) for deciduous forests (Querco-Fagetea, 8.5\% and 6.8\% respectively), and for ruderal and forest-edge habitats (Artemisietea vulgaris, $14.0 \%$ and $12.3 \%$ respectively). In the whole-city flora there were higher shares of ruderal and crop weed species (Stellarietea mediae, $12.2 \%$ while $9.0 \%$ in the ecological lands) and grassland species (FestucoBrometea, $5.3 \%$ and $4.3 \%$ respectively).

\section{Functional traits range}

Ecological lands contained a high functional traits range, compared to the flora of the whole city. In four categorical traits, all levels present in the whole-city flora were represented on ecological lands (Table 3). For dispersal modes and types of leaf distribution, we did not find any mode which would be not represented in the ecological lands studied. In comparison with flora of the whole city, ecological lands had lower proportions of therophytes and species representing a ruderal life 


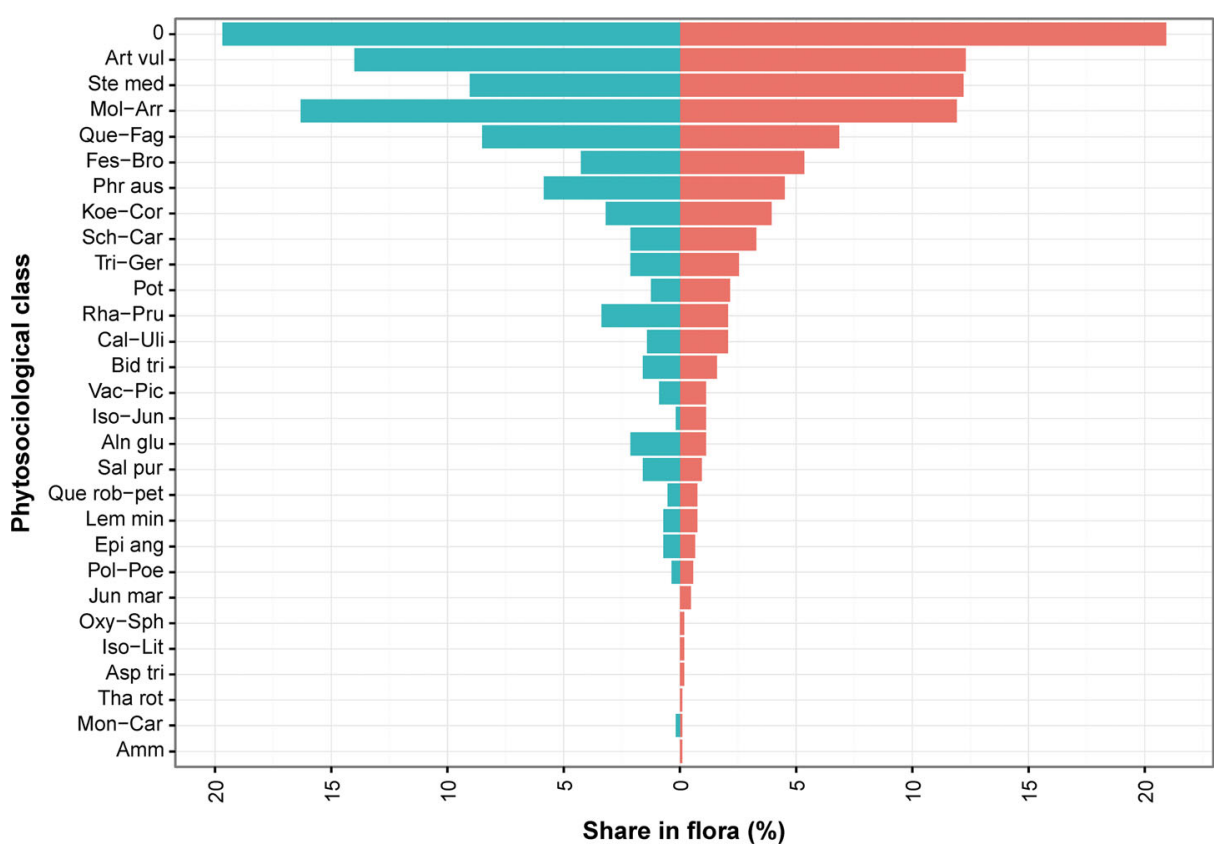

Fig. 2 Share (\%) of species representing phytosociological classes in flora of ecological lands (blue, left-side) and the whole city (red, rightside). Abbreviations: 0 - species not belonging to any phytosociological class, Art vul - Artemisietea vulgaris (ruderal and fertile forest edges vegetation), Ste. med - Stellarietea mediae (ruderal and crop weeds vegetation), Mol-Arr - Molinio-Arrhenatheretea (meadows and pastures), Que.-Fag - Querco-Fagetea (fertile and mesotrophic deciduous forests), Fes-Bro - Festuco-Brometea (xerothermophilous grasslands), Phr aus - Phragmitetea australis (reeds and sedges), KoeCor - Koelerio-Corynephoretea (dry, sandy grasslands), Sch-Car Scheuchzerio-Caricetea (peat bogs, mainly transitional), Tri-Ger Trifolio-Geranietea (termophilous forest-edges), Pot - Potametea (open waters), Rha-Pru - Rhamno-Prunetea (shrubs), Cal-Uli - CallunoUlicetea (heatlands and Nardus grasslands), Bid tri - Bidentetea

strategy. Flora of ecological lands contained a full spectrum of almost all of Ellenberg's ecological indicator values, except for two indicators: the continentality index and soil reaction index (Fig. 3, Table 4). For the continentality index species with the 8th degree (species typical to continental climate) were absent on ecological lands, while five species were present (Atriplex tatarica, Iva xanthiifolia, Lepidium latifolium, Leonurus marrubiastrum, Silene chlorantha) in the wholecity flora. For the case of soil reaction index, species with the 1st degree (typical to extremely acid soils) were absent on ecological lands, whereas five species were present (Calluna vulgaris, Diphasium complanatum, Drosera rotundifolia, Pedicularis sylvatica and Teesdalea nudicaulis) for the whole city. For the case of continuous numeric traits, the flora of ecological lands contained from 95.8 to $100 \%$ of values of the whole-city distribution (Fig. 4, Table 4). The lowest quantile range of traits was found in canopy height, due to lack of plants with the lowest height in ecological lands studied, and the highest range was found for SLA and seed weight, where the whole spectrum of traits for the city was also found on ecological lands. tripartitae (muds and inundation-zone), Vac-Pic - Vaccinio-Piceetea (coniferous forests), Iso-Jun - Isoëto durieui-Juncetea bufonii (astatic ponds and inundation-zone), Aln glu - Alnetea glutinosae (alder carrs and willow shrubs), Sal pur - Salicetea purpureae (riparian Salix and Populus forests), Que. rob-pet - Quercetea roboris-petraeae (acidophilus Quercus forests), Lem min - Lemnetea minoris (floating duckweeds), Epi ang - Epilobietea angustifoliae (forest clear cuttings and forest edges), Pol-Poe - Polygono-Poetea annuae (pioneer vegetation of trodden place), Jun mar - Juncetea maritimi (salt meadows), Oxy-Sph - Oxycocco-Sphagnetea (raised bogs), Iso-Lit Isoëto-Litorelletea (oligotrophic and dystrophic lakes, astatic ponds), Asp tri - Asplenietea trichomanis (rocks and walls), Tha rot Thlaspietea rotundifolii (mountain rocky screes), Mon-Car - MontioCardaminetea (springs), Amm - Ammophiletea (sand dunes)

\section{Discussion}

Our study proved that in the urban environment small, but well-chosen, green areas protected by law as ecological lands, may be an efficient way of plant species diversity conservation. On less than $2 \%$ of the city area, over $50 \%$ of taxonomical, over $75 \%$ of phytosociological and over $95 \%$ of functional diversity is protected.

For a real assessment of conservation value of ecological lands, it is necessary to compare species diversity with diversity of non-protected areas. In Poznań, due to the small amount of data about vascular plants in non-protected areas, there is a problem with strict comparison. However, Jackowiak (1993, 1998) analyzed the flora of the whole city and found that species richness per $1 \mathrm{~km}^{2}$ grid square ranged from 40 to over 340 species, with a median of 150 . In the zone of high buildings around the city centre it was an average of 126 , in the zone of low buildings - 146, in the zone of scattered buildings, gardens, fields and wastelands -170 and in the zone of forests and wetlands, the most preserved within the city -140 species per $1 \mathrm{~km}^{2}$. In Warsaw the mean number of plant species per 
Table 3 Proportion of levels of categorical functional traits in flora of ecological lands studied

Dispersion mode (definitions by Hintze et al. 2013)

autochor - dispersed as a result of forces that are mediated by the plant or its tissues

hemerochor - dispersed by human and human activities

endozoochor - dispersed by digestive system of animals

epizoochor - dispersed hooked to fur of animals

ethelochor - dispersed as diaspores or whole plants are commercially used

boleochor - dispersed by the wind

nautochor - dispersed by the water

speirochor - dispersed by seed contamination

agochor - dispersed unintentionally by human activities

ombrochor - dispersed by throwing away from the mother plant, facilitated by falling raindrops

meteorochor - dispersed by the wind

dysochor - dispersed by animals which are storage diaspores, e.g. rodents

chamaechor - diaspores tumble away on the ground in the wind

ballochor - dispersed by active release from the plant, e.g. due to tissue tension

zoochor - dispersed by animals

bythisochor - dispersed by the water currents

blastochor - dispersed by putting down in short distance, still connected to the mother plant

herpochor - diaspores contain morphological or anatomical structures that generate movement

on the ground over short distances

Leaves distribution

leaves distributed regularly along the stem

semi-rosette

rosette / tufted plant above ground, above ground in water or on water surface

shoot scarcely foliated

tufts and crowns, leaves concentrated as a rosette at the top of taller shoot or vegetative stem

Life form

geophyte - perennials with buds underground, e.g. in rhizomes or tubers

therophyte - annuals, reproducing exclusively by seeds

hemicryptophyte - perennials with buds at the ground level, in leaves rosette

phanerophyte - perennials with buds on woody pods, $>50 \mathrm{~cm}$ height

chamaephyte - perennials with buds on woody pods, $<50 \mathrm{~cm}$ height

liana - any of various woody climbing plant species

hydrophyte - perennials with buds under the water surface

Life strategy

$\mathrm{c}$ - competitors

csr - mixed strategy (competitors/stress tolerators/ ruderals)

cs - mixed strategy (competitors/stress tolerators)

$\mathrm{cr}-$ mixed strategy (competitors/ruderals)

$\mathrm{r}$ - ruderals

$\mathrm{s}$ - stress tolerators

$\mathrm{sr}$ - mixed strategy (stress tolerators/ruderals)
66.1

6.1

72.9

4.6

50.5

55.7

40.6

20.0

67.9

20.2

32.6

9.9

28.7

35.1

4.4

8.0

74.1

0.7

2.8

1.2

0.9

59.8

65.1

46.2

41.8

9.1

9.0

1.3

0.8

1.4

0.5

11.0

12.4

21.9

16.8

$44.5 \quad 48.0$

$7.7 \quad 13.3$

$5.3 \quad 5.9$

$3.1 \quad 3.5$

$6.8 \quad 6.9$

24.6

35.1

21.7

20.9

16.8

17.4

13.7

11.2

8.8

5.7

2.0

1.4

4.8

Percents do not sum to $100 \%$, due to lack of data in databases and non-exclusiveness (i.e. one species may have several levels of a trait)

$2.25 \mathrm{~km}^{2}$ varied between anthropopressure zones: from 178 in the most urbanized zone to 305 in the least urbanized zones (i.e. from 79 to 136 per $1 \mathrm{~km}^{2}$ ). Ecological lands studied host 445,341 and 322 species, which per $1 \mathrm{~km}^{2}$ is 280,438 and
341 species (Table 1). All of them host ca. twice the number of species than an average urban area and at least $60 \%$ more than an average grid square in the most species-rich zone in Poznań. Ecological lands studied are also richer in species than 
Fig. 3 Share (\%) of species representing degrees of Ellenberg's ecological indicator values in flora of ecological lands (blue, lower part) and the whole city (red, upper part). Ellenberg's indicators: L. - light, $\mathrm{T}-$ temperature, $\mathrm{C}$ - continentality, $\mathrm{M}$ - moisture, SR - soil reaction, $\mathrm{N}$ - fertility; NA - species with not available data or wider ecological amplitudes
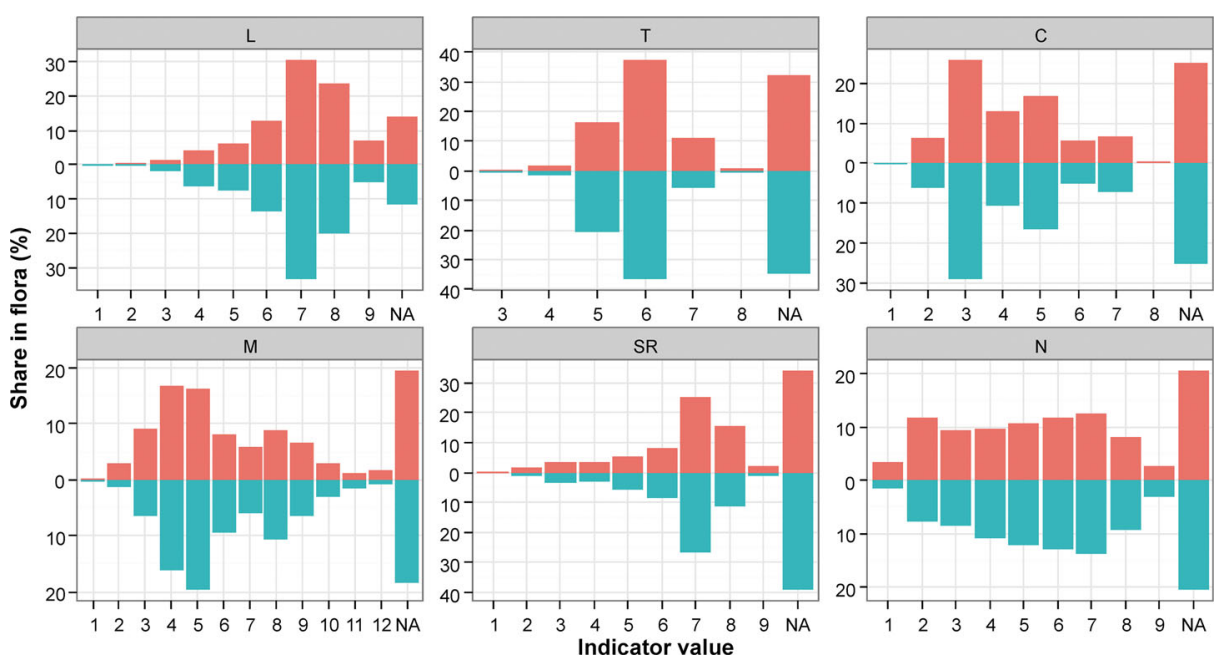

the recreational green area near the Rusałka lake in Poznań, which covers 138.9 ha and hosts 314 species of plants (Dyderski et al., unpublished). Comparison with nature reserves in Poznań is difficult, as there are only two and there are no published floristic lists for them. In other cities nature reserves may host various numbers of species. In Warsaw, the forest nature reserve 'Las Bielański' hosts over 400 species of plants, with an area of 151.8 ha (Chojnacki et al. 2002), and in Łódź the 70 ha reserve 'Las Łagiewnicki' hosts 279 species (Witosławski et al. 2000). For example, in Prague (Czech Republic), in 48 reserves with an area of 0.5 to 225 ha (with an average of 38.0 ha) there were 117 to 696 species of vascular plants (with an average of 299), however species richness strongly depended on landscape heterogeneity (Jarošík et al. 2011a). Thus, we can say that the ecological lands studied host similar species richness as nature reserves.

High level of vascular plant functional traits range, compared with the whole-city flora, probably results from making good choices of areas with high conservation values for protection. The ecological lands studied were created based on expert knowledge of biodiversity scientists, who gave advice on areas with the highest levels of species and habitat diversity to protect. Most of the former ecological lands (22 in 2004; Dyderski and Wrońska-Pilarek 2015a) lost their legal status due to changes in the Nature Conservation Act in 2004, and

Table 4 Summary of the ordered and numeric traits in flora of the whole city and ecological lands studied

\begin{tabular}{|c|c|c|c|c|c|c|c|c|c|}
\hline \multirow[t]{2}{*}{ Trait } & \multicolumn{6}{|c|}{ Ecological lands studied } & \multicolumn{3}{|c|}{ Whole city } \\
\hline & $\min$ & $\left(\right.$ percentile $^{1}$ ) & $\max$ & $\left(\right.$ percentile $\left.^{1}\right)$ & median & range $(\%)^{2}$ & $\min$ & median & $\max$ \\
\hline Light & 1 & - & 9 & - & 7 & 100 & 1 & 7 & 9 \\
\hline Temperature & 3 & - & 8 & - & 6 & 100 & 3 & 6 & 8 \\
\hline Continentality & 1 & - & 7 & - & 4 & 87.5 & 1 & 4 & 8 \\
\hline Moisture & 1 & - & 12 & - & 6 & 100 & 1 & 6 & 12 \\
\hline Soil reaction & 2 & - & 9 & - & 7 & 88.9 & 1 & 7 & 9 \\
\hline Soil fertility & 1 & - & 9 & - & 5 & 100 & 1 & 5 & 9 \\
\hline Canopy height & $<0.10$ & 4.20 & 50.00 & 100 & 0.48 & 95.8 & $<0.1$ & 0.41 & 50.00 \\
\hline Leaf dry mass content & 46.7 & 0.10 & 492.2 & 99.9 & 213.3 & 99.8 & 46.7 & 201.4 & 510.0 \\
\hline Leaf mass & 0.2 & 0.3 & 5603.1 & 99.7 & 59.9 & 99.4 & 0.1 & 44.3 & 13189.7 \\
\hline Leaf size & $<0.1$ & 1 & 117000 & 99.8 & 1436 & 99.3 & $<0.1$ & 1087 & 332250 \\
\hline Specific leaf area & 2.97 & 0.00 & 144.78 & 100 & 23.92 & 100.0 & 2.97 & 23.68 & 144.78 \\
\hline Seed weight & $<0.1$ & 0 & 12500 & 100 & 1 & 100.0 & $<0.1$ & 1 & 12500 \\
\hline Seed number per shoot & 0 & 0.6 & 13216382 & 99.9 & 6646 & 99.3 & 0 & 3500 & 300000000 \\
\hline
\end{tabular}

${ }^{1}$ percentiles show how much of minimal and maximal traits' values represented in the whole city are not represented in ecological lands studied; ${ }^{2}$ range was calculated as proportion of traits distribution in flora of the whole city represented in ecological lands studied; in case of ordinal traits (Ellenberg's ecological indicators) it was proportion of levels represented, in case of numeric traits - range of distribution, calculated as difference between minimum and maximum values of trait in the flora of ecological lands studies percentiles of the flora of whole city 
Fig. 4 Distributions of species' numeric functional traits in flora of ecological lands (blue) and the whole city (red). Distributions are shown by violin plots - the wider the shape is, the more frequent the particular value of the trait is. Dots inside the violins indicate medians. Leaf dmc - leaf dry matter content, seed nps - seed number per shoot. For units see Table 2. Axis $\mathrm{Y}$ was log-scaled
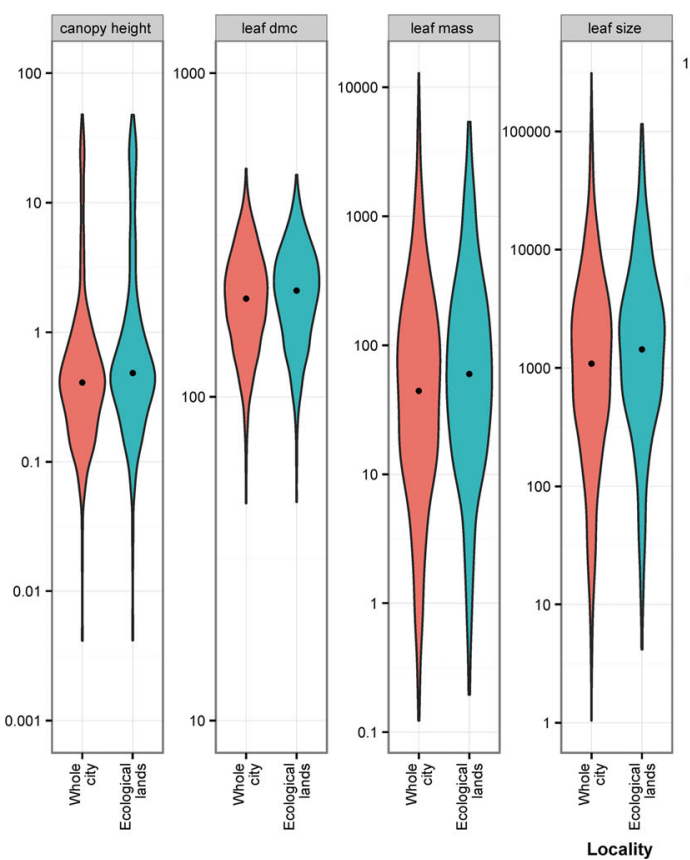

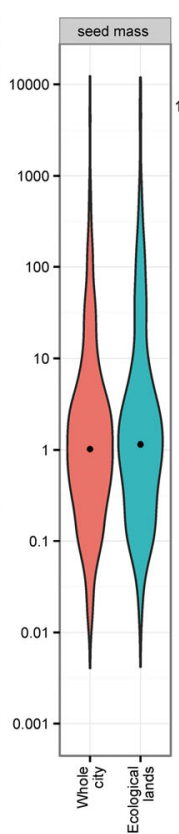

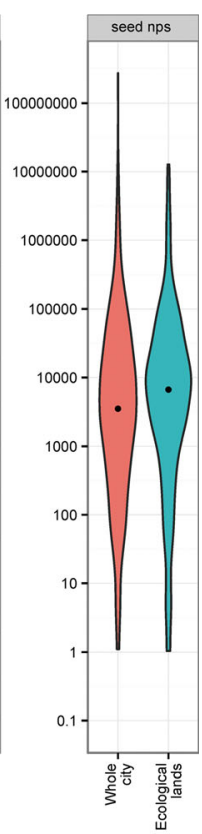

only a few of them were reinstated. However, our findings show the importance of decisions made about locality of protected areas in the city. This is especially significant, because most urban areas have higher species richness than rural areas (Turner et al. 2004; Kühn et al. 2004; Araújo 2003). High spatial heterogeneity of ecological lands studied (Table 1) resulted in presence of habitats with different levels of anthropogenic transformation or, according to Kowarik's (2011) concept of 'four natures' - all of the 'natures' present in urban ecosystems. The wide spectrum of functional plant types reflects this habitat heterogeneity of ecological lands studied, which is one of the most important drivers of plants species richness in urban environments (Jarošík et al. 2011a; Beninde et al. 2015). Moreover, the ecological lands studied are located in river valleys, which are important habitats for many groups of plants, especially woodland species (Naiman et al. 1993; Richardson et al. 2007; Stefańska-Krzaczek 2013). Thus, proper selection of habitats and inclusion of different states of preservation, are crucial in protecting nature conservation areas in cities.

Analysis of phytosociological affiliation of species revealed that on ecological lands some groups of species are less represented, in comparison with the flora of the whole city. For example, species typical of crop weed plant communities (Stellarietea mediae), which frequently are therophytes with ruderal life strategies. Lower number of these species are connected with relatively low representation of crops within the borders of ecological lands studied (only in 'Bogdanka'), in contrast to the whole city, where arable lands comprises $22 \%$ of the city (Jackowiak 2011). This class also contains a high number of archaeophytes, which are also less represented in the flora of ecological lands studied (in comparison with the whole city). However, these groups of species are considered to benefit from urbanity (Jackowiak 2000; Chocholoušková and Pyšek 2003; Knapp et al. 2009; Knapp et al. 2010; Williams et al. 2015). Classes which had low representation in the flora of ecological lands, were represented by few species in the whole city, as their typical habitats were poorly represented in the city (e.g. raised bogs, which degraded due to lowering of the groundwater table) or these species occurred in secondary habitats, e.g. species from Asplenietea trichomanis occur in city in brick walls and species from Juncetea maritimi occur near roads, which in winter are treated with salt (Jackowiak 1982).

Global synthesis of plant extinctions in cities (Hahs et al. 2009) has shown that urban ecosystems with lower proportions of alien species in the flora are more stable and less vulnerable to native plant species extinctions. In comparison with flora of other cities, Poznan's proportion of alien plant species (30.6\%; Jackowiak 2011) is lower than an average of Central European cities (40.3\%; Pyšek 1998), and this proportion is much lower in the ecological lands studied (23.0\%), which may be connected with the high richness of native vascular plant species. It may also be connected with a lower-severity disturbance regime and high cover of forests, which are less invasible than industrial areas, arable land, gardens and parks (Lambdon et al. 2008). However, in ecological lands studied there was a higher share of phanerophytes, usually alien woody species. This may be connected with neighbourhood garden plots and managed green areas, which contain their propagule sources (Kowarik 2011; Kowarik et al. 2013; Dyderski et al. 2015a; Speak et al. 2015). 
One of rules of thumb in nature conservation is the bigger a protected area is, the better it may protect the ecological processes within. This approach may be applied in cases of extensive areas with low human activity, especially to conserve areas not transformed by human activities. However, this concept is discussed as the so-called SLOSS debate, regarding whether single large or several small areas should be established for conservation purposes (e.g. Lomolino 1994; Ovaskainen 2002). In cities, where the only remnants of natural areas are small and readily available to residents, and often used for recreation, it is impossible to create large protected areas. Niemelä (1999) claims that in urban areas it is difficult to apply the SLOSS concept, as there is no source area (mainland in island biogeography theory), however in the case of plants it has not been clarified whether green areas within cities are sources or sinks of plant species. It is equivocal, as within the city green areas may be sources of native, specialized species and sinks for alien, cosmopolitan species. It results from prevalence of different processes shaping urban plant metacommunities, depending on social investment (i.e. impact of human activities according to Swan et al. (2011)) in ecological community composition. This investment is low in more natural patches, where alpha diversity is driven mainly by environmental filtering and high in man-made habitats, where alpha diversity is driven mainly by dispersal and environmental facilitation (Swan et al. 2011). Information on metacommunity dynamics of plant communities in cities is scarce, as a majority of studies conducted have concerned birds (Szlavecz et al. 2011). The relatively small area of ecological lands, in comparison with the whole city, might be not sufficient to preserve species richness in the long run. Beninde et al. (2015) found that in urban areas 53.3 ha is a threshold area for conservation of urban-avoiding species, and the ecological lands studied are larger (Table 1). Moreover, all of them are located in ecological corridors - river valleys, which allow species migration (Naiman et al. 1993) and are very important for conserving urban biodiversity (Beninde et al. 2015). Therefore, for planning biodiversity conservation in urban habitat patches, precise recognition of species composition and distributions is necessary, especially in terms of ecological connectivity between patches and minimal area of ecological lands.

An important benefit connected with biodiversity conservation in low-restrictive forms of protected areas, is access to them by urban inhabitants. Access by people into natural habitats improves quality of life and increases social acceptance for nature conservation efforts (Turner et al. 2004). A high number of restrictions on use by local residents may also result in lack of acceptance and respect, especially when activities which local inhabitants used to practice before designation as a nature reserve, are restricted (Seeland et al. 2002). For example, according to the Polish Nature Conservation Act (Ustawa z dnia 16 kwietnia 2004 r. o ochronie przyrody
2004), it is forbidden to walk off of the paths and to walk dogs in nature reserves, but these prohibitions are not allowed on ecological lands. However, some activities and changes can be prohibited on ecological lands such as land-cover changes, activities leading to hydrological balance changes, elimination of reservoirs, harvesting animals, fungi and plants or peat extraction. Thus, introduction of less-restrictive forms of protected areas may be a good compromise between biodiversity conservation and recreational needs of inhabitants.

\section{Conclusions}

Ecological lands seem to be a good way to conserve biodiversity in urban areas. Our results show that even an area as small as $1.8 \%$ of the whole city may host over $50 \%$ of taxonomical diversity of flora and over $95 \%$ of plant functional traits range. The legislative simplicity and low restrictiveness for both land management and recreational utility make ecological lands a much easier form of nature conservation which may be adapted in other cities for more efficient biodiversity management.

Acknowledgements The study was financially supported by the Institute of Dendrology, Polish Academy of Sciences, Kórnik, Poland. We kindly thank Dr. Lee E. Frelich (The University of Minnesota Center for Forest Ecology, USA) for valuable comments to the manuscript and linguistic support. We declare that the study complies with the current laws of Poland. We are grateful to two anonymous Reviewers who helped us improve the first draft of the manuscript.

Open Access This article is distributed under the terms of the Creative Commons Attribution 4.0 International License (http:// creativecommons.org/licenses/by/4.0/), which permits unrestricted use, distribution, and reproduction in any medium, provided you give appropriate credit to the original author(s) and the source, provide a link to the Creative Commons license, and indicate if changes were made.

\section{References}

Alvey AA (2006) Promoting and preserving biodiversity in the urban forest. Urban For Urban Green 5:195-201. doi:10.1016/j. ufug.2006.09.003

Araújo MB (2003) The coincidence of people and biodiversity in Europe. Glob Ecol Biogeogr 12:5-12. doi:10.1046/j.1466-822 X.2003.00314.x

Aronson MF, La Sorte FA, Nilon CH, Katti M, Goddard MA, Lepczyk CA, Warren PS, Williams NS, Cilliers S, Clarkson B (2014) A global analysis of the impacts of urbanization on bird and plant diversity reveals key anthropogenic drivers. Proc R Soc Lond B Biol Sci 281:20133330. doi:10.1098/rspb.2013.3330

Beninde J, Veith M, Hochkirch A (2015) Biodiversity in cities needs space: a meta-analysis of factors determining intra-urban biodiversity variation. Ecol Lett 18:581-592. doi:10.1111/ele.12427

Chocholoušková Z, Pyšek P (2003) Changes in composition and structure of urban flora over 120 years: a case study of the city of Plzeň. Flora 198:366-376. doi:10.1078/0367-2530-00109 
Chojnacki J, Czajka J, Luniak M, Miścicki S, Namura-Ochalska A (2002) Raport o wartości i stanie przyrody Lasu Bielańskiego. URL: http://www.lasbielanski.waw.pl. Accessed 21 Aug 2016

Clark JR, Matheny NP, Cross G, Wake V (1997) A model of urban forest sustainability. J Arboric 23:17-30

Core Team R (2015) R: A language and environment for statistical computing. R Foundation for Statistical Computing, Vienna, Austria https://www.r-project.org/

Czech B, Krausman PR, Devers PK (2000) Economic associations among causes of species endangerment in the United States. Bioscience 50:593-601. doi:10.1641/0006-3568(2000)050[0593 :EAACOS]2.0.CO;2

Dearborn DC, Kark S (2010) Motivations for conserving urban biodiversity. Conserv Biol 24:432-440. doi:10.1111/j.15231739.2009.01328.x

DeCandido R (2004) Recent changes in plant species diversity in urban Pelham Bay park, 1947-1998. Biol Conserv 120:129-136. doi:10.1016/j.biocon.2004.02.005

Diekmann M (2003) Species indicator values as an important tool in applied plant ecology - a review. Basic Appl Ecol 4:493-506. doi:10.1078/1439-1791-00185

Dudley N (ed) (2008) Guidelines for applying protected area management categories. IUCN, Gland, Switzerland

Dyderski MK, Jagodziński AM (2014) Synantropizacja zbiorowisk łęgowych ze związku Salicion albae w południowej części Poznania. Acta Bot Sil 10:41-69

Dyderski MK, Jagodziński AM (2016) Patterns of plant invasions at small spatial scale correspond with that at the whole country scale. Urban Ecosyst 19:983-998. doi:10.1007/s11252-015-0524-y

Dyderski MK, Wrońska-Pilarek D (2015a) Szata roślinna nowo powstałych użytków ekologicznych "Dębina I" i "Dẹbina II" w Poznaniu. Nauka Przyr Technol 9:46. doi:10.17306/J. NPT.2015.4.46

Dyderski MK, Wrońska-Pilarek D (2015b) Szata roślinna nowo powstałego użytku ekologicznego "Strzeszyn" w Poznaniu i stan jej zachowania. Nauka Przyr Technol 9:39. doi:10.17306/J. NPT.2015.3.39

Dyderski MK, Gdula AK, Wrońska-Pilarek D (2014a) Rośliny naczyniowe nowo utworzonych użytków ekologicznych "Bogdanka I" i "Bogdanka II" w Poznaniu. Nauka Przyr Technol 8:44

Dyderski MK, Gdula AK, Wrońska-Pilarek D (2014b) Roślinność nowo utworzonych użytków ekologicznych Bogdanka I i Bogdanka II w Poznaniu. Acta Sci Pol Silv Colendar Rat Ind Lignaria 13:22-37

Dyderski MK, Gdula AK, Jagodziński AM (2015a) "the rich get richer" concept in riparian woody species - a case study of the Warta River valley (Poznań, Poland). Urban For Urban Green 14:107-114. doi:10.1016/j.ufug.2014.12.003

Dyderski MK, Gdula AK, Wrońska-Pilarek D (2015b) Wpływ antropopresji na leśne zbiorowiska roślinne w warunkach aglomeracji miejskiej na przykładzie Doliny Bogdanki w Poznaniu. Studia Mat CEPL w Rogowie 42:84-94

Dzwonko Z (2001) Assessment of light and soil conditions in ancient and recent woodlands by Ellenberg indicator values. J Appl Ecol 38: 942-951. doi:10.1046/j.1365-2664.2001.00649.x

Ellenberg H, Leuschner C (2010) Vegetation Mitteleuropas mit den Alpen in ökologischer, dynamischer und historischer Sicht. UTB, Stuttgard

Environment Protection (2014) Statistical yearbook. Główny Urząd Statystyczny, Warszawa

Godefroid S, Koedam N (2003) How important are large vs. small forest remnants for the conservation of the woodland flora in an urban context? Glob Ecol Biogeogr 12:287-298. doi:10.1046/j.1466-822 X.2003.00035.x

Grime PJ (1979) Plant Strategies and Vegetation Processes. John Wiley \& Son, Chichester
Hahs AK, McDonnell MJ, McCarthy MA, Vesk PA, Corlett RT, Norton BA, Clemants SE, Duncan RP, Thompson K, Schwartz MW, Williams NSG (2009) A global synthesis of plant extinction rates in urban areas. Ecol Lett 12:1165-1173. doi:10.1111/j.14610248.2009.01372.x

Halarewicz A, Żołnierz L (2014) Changes in the understorey of mixed coniferous forest plant communities dominated by the American black cherry (Prunus serotina Ehrh.). For Ecol Manag 313:91-97. doi:10.1023/A:1023208215796

Hintze C, Heydel F, Hoppe C, Cunze S, König A, Tackenberg O (2013) D3: the dispersal and diaspore database - baseline data and statistics on seed dispersal. Perspect Plant Ecol 15:180-192. doi:10.1016/j. ppees.2013.02.001

Horsák M, Lososová Z, Čejka T, Juřičková L, Chytrỳ M (2013) Diversity and biotic homogenization of urban land-snail faunas in relation to habitat types and macroclimate in 32 central European cities. PLoS One 8:e71783. doi:10.1371/journal.pone.0071783

Jackowiak B (1982) Występowanie Puccinellia distans (Jacq.) Parl. na terenie miasta Poznania. Bad Fizjogr Pol Zach B 33:129-142

Jackowiak B (1990) Antropogeniczne przemiany flory roślin naczyniowych Poznania. Wydawnictwo Naukowe UAM, Poznań

Jackowiak B (1993) Atlas rozmieszczenia roślin naczyniowych w Poznaniu. Bogucki Wydawnictwo Naukowe, Poznań

Jackowiak B (1995) Uwagi o zagrożeniu flory naczyniowej Poznania. In: Żukowski W, Jackowiak B (eds) Ginące i zagrożone rośliny naczyniowe Pomorza Zachodniego. Bogucki Wydawnictwo Naukowe, Poznań, pp. 95-98

Jackowiak B (1998) Struktura przestrzenna flory dużego miasta. Studium metodyczno-problemowe, Bogucki Wydawnictwo Naukowe, Poznań

Jackowiak B (2000) Chorological and ecological model of Urbanophilous Plant in Central Europe. In: Jackowiak B, Żukowski W (eds) Mechanisms of anthropogenic changes of the plant cover. Bogucki Wydawnictwo Naukowe, Poznań, pp. 125-141

Jackowiak B (2011) Poznań. In: Müller N, Kelcey JG (eds) Plants and habitats of European cities. Springer, New York, pp. 363-405

Jarošík V, Konvička M, Pyšek P, Kadlec T, Beneš J (2011a) Conservation in a city: do the same principles apply to different taxa? Biol Conserv 144:490-499. doi:10.1016/j.biocon.2010.10.002

Jarošík V, Pyšek P, Kadlec T (2011b) Alien plants in urban nature reserves: from red-list species to future invaders? NeoBiota 10:27-46. doi:10.3897/neobiota.10.1262

Jaszczak R, Wajchman S (2014) Problems of Forest Management in Municipal Forests of the City of Poznań. Civil Environ Eng Rep 12:45-54. doi:10.2478/ceer-2014-0005

Kleyer M, Bekker RM, Knevel IC, Bakker JP, Thompson K, Sonnenschein M, Poschlod P, Van Groenendael JM, Klimeš L, Klimešová J, Klotz S, Rusch GM, Hermy M, Adriaens D, Boedelthje G, Bossuyt B, Dannemann A, Endels P, Götzenberger L, Hodgson JG, Jackel A-K, Kühn I, Kunzmann D, Ozinga WA, Römermann C, Stadler M, Schlegelmilch M, Steendam HJ, Teckenberg O, Wilmann B, Cornelissen JH, Eriksson O, Garnier E, Peco B (2008) The LEDA Traitbase: a database of life-history traits of the northwest European flora. J Ecol 96:1266-1274. doi:10.1111/j.1365-2745.2008.01430.x

Klotz S, Kühn I, Durka W (2002) BIOLFLOR-Eine Datenbank zu biologisch-ökologischen Merkmalen der Gefäßpflanzen in Deutschland. Schriftenreihe für Vegetationskunde. Bundesamt für Naturschutz, Bonn

Knapp S, Kühn I, Bakker JP, Kleyer M, Klotz S, Ozinga WA, Poschlod P, Thompson K, Thuiller W, Römermann C (2009) How species traits and affinity to urban land use control large-scale species frequency. Divers Distrib 15:533-546. doi:10.1111/j.1472-4642.2009.00561.x

Knapp S, Kühn I, Stolle J, Klotz S (2010) Changes in the functional composition of a central European urban flora over three centuries. Perspect Plant Ecol 12:235-244. doi:10.1016/j.ppees.2009.11.001 
Kowarik I (2011) Novel urban ecosystems, biodiversity, and conservation. Environ Pollut 159:1974-1983. doi:10.1016/j. envpol.2011.02.022

Kowarik I, Lippe M, Cierjacks A (2013) Prevalence of alien versus native species of woody plants in berlin differs between habitats and at different scales. Preslia 85:113-132

Kühn I, Brandl R, Klotz S (2004) The flora of German cities is naturally species rich. Evol Ecol Res 6:749-764

Lambdon PW, Pyšek P, Basnou C, Hejda M, Arianoutsou M, Essl F, Jarošík V, Pergl J, Winter M, Anastasiu P, Andriopoulos P, Bazos I, Brundu G, Celesti-Grapow L, Chassot P, Delipetrou P, Josefsson M, Kark S, Klotz S, Kokkoris Y, Kühn I, Marchante H, Perglová I, Pino J, Vilá M, Zikos A, Hulme PE (2008) Alien flora of Europe: species diversity, temporal trends, geographical patterns and research needs. Preslia 80:101-149

Lomolino MV (1994) An evaluation of alternative strategies for building networks of nature reserves. Biol Conserv 69:243-249. doi:10.1016 /0006-3207(94)90423-5

McKinney ML (2006) Urbanization as a major cause of biotic homogenization. Biol Conserv 127:247-260. doi:10.1016/j. biocon.2005.09.005

McPherson EG (2006) Urban forestry in North America. Renewable Resour Journal 24:8

Miller JR, Hobbs RJ (2002) Conservation where people live and work. Conserv Biol 16:330-337. doi:10.1046/j.1523-1739.2002.00420.x

Mirek Z, Piękoś-Mirkowa H, Zając A, Zając M (2003) Flowering plants and pteridophytes of Poland. A checklist. W. Szafer Institute of Botany, PAN, Kraków

Mölder A, Schneider E (2011) On the beautiful diverse Danube? Danubian floodplain forest vegetation and flora under the influence of river eutrophication. River Res Appl 27:881-894. doi:10.1002/rra.1403

Naiman RJ, Decamps H, Pollock M (1993) The role of riparian corridors in maintaining regional biodiversity. Ecol Appl 3:209-212

Niemelä J (1999) Ecology and urban planning. Biodivers Conserv 8:119 131. doi:10.1023/A:1008817325994

Obidziński T, Symonides E (2000) The influence of the groundlayer structure on the invasion of small balsam (Impatiens parviflora DC.) to natural and degraded forests. Acta Soc Bot Pol 69:311318. doi:10.5586/asbp.2000.041

Olden JD, LeRoy PN, Douglas MR, Douglas ME, Fausch KD (2004) Ecological and evolutionary consequences of biotic homogenization. Trends Ecol Evol 19:18-24. doi:10.1016/j.tree.2003.09.010

Ovaskainen O (2002) Long-term persistence of species and the SLOSS problem. J Theor Biol 218:419-433. doi:10.1006/jtbi.2002.3089

Przyroda miasta Poznania (2009) Wydział Ochrony Środowiska Urzędu Miasta Poznania, Poznań

Pyšek P (1998) Alien and native species in central European urban floras: a quantitative comparison. J Biogeogr 25:155-163. doi:10.1046 /j.1365-2699.1998.251177.x

Ratyńska H, Wojterska M, Brzeg A, Kołacz M (2010) Multimedialna encyklopedia zbiorowisk roślinnych Polski. NFOSiGW, UKW, IETI

Richardson DM, Holmes PM, Esler KJ, Galatowitsch SM, Stromberg JC, Kirkman SP, Pyšek P, Hobbs RJ (2007) Riparian vegetation: degradation, alien plant invasions, and restoration prospects. Divers Distrib 13:126-139. doi:10.1111/j.1366-9516.2006.00314.x

Samu F, Szinetár C (2000) Rare species indicate ecological integrity: an example of an urban nature Reserve Island. In: Crabbé P, Holland A, Ryszkowski L, Westra L (eds) Implementing ecological integrity. Springer, Berlin, pp. 177-184
Schaffers AP, Sýkora KV (2000) Reliability of Ellenberg indicator values for moisture, nitrogen and soil reaction: a comparison with field measurements. J Veg Sci 11:225-244. doi:10.2307/3236802

Seeland K, Moser K, Scheuthle H, Kaiser FG (2002) Public acceptance of restrictions imposed on recreational activities in the peri-urban nature reserve Sihlwald, Switzerland. Urban For Urban Green 1:4957. doi:10.1078/1618-8667-00006

Solińska-Górnicka B, Symonides E (1990) Effect of a large city on the structure of coenoelements in a natural woodland in Warsaw. Vegetatio 88:163-176. doi:10.1007/BF00044833

Speak AF, Mizgajski A, Borysiak J (2015) Allotment gardens and parks: provision of ecosystem services with an emphasis on biodiversity. Urban For Urban Green 14:772-781. doi:10.1016/j. ufug.2015.07.007

Statistical Yearbook of Poznań city (2013) Statistical Office in Poznań, Poznań

Stefańska-Krzaczek E (2013) Bogactwo gatunkowe osuszonych lasów łegowych w środowisku miejskim Wrocławia. Sylwan 157:366-375

Swan CM, Pickett STA, Szlavecz K, Warren P, Willey KT (2011) Biodiversity and community composition in urban ecosystems: coupled human, spatial, and metacommunity processes. In: Breuste JH, Elmqvist T, Guntenspergen G, James P, McIntyre NE (eds) Urban ecology. Oxford University Press, Oxford, pp. 179-186

Szlavecz K, Warren P, Pickett S (2011) Biodiversity on the urban landscape. In: Cincotta RP, Gorenflo LJ (eds) Human Population. Springer, Berlin Heidelberg, pp. 75-101

Turner WR, Nakamura T, Dinetti M (2004) Global urbanization and the separation of humans from nature. Bioscience 54:585-590. doi:10.1641/0006-3568(2004)054[0585:GUATSO]2.0.CO;2

Ustawa z dnia 16 kwietnia 2004 r. o ochronie przyrody. (2004). Dz. U. 2004 nr 92 poz. 880

Williams NSG, Hahs AK, Vesk PA (2015) Urbanisation, plant traits and the composition of urban floras. Perspect Plant Ecol 17:78-86. doi:10.1016/j.ppees.2014.10.002

Witosławski P, Andrzejewski H, Kurowski JK (2000) Flora naczyniowa rezerwatu Las Łagiewnicki w Łodzi. Acta Univ Lod Fol Bot 14:5-24

Wojterski T, Wojterska H, Wojterska M (1982) Mapa potencjalnej roślinności naturalnej środkowej Wielkopolski. Bad Fizjogr Pol Zach B 32:7-35

Woziwoda B, Kopeć D (2014) Afforestation or natural succession? Looking for the best way to manage abandoned cut-over peatlands for biodiversity conservation. Ecol Eng 63:143-152. doi:10.1016/j. ecoleng.2012.12.106

Wrońska-Pilarek D (2008) Vascular plants of "Strzeszyn" ecological site in Poznań. Acta Sci Pol Silv Colendar Rat Ind Lignaria 7:79-91

Wrońska-Pilarek D (2010) The vascular plants of the former ecological site "Bogdanka" in Bogdanka river valley in Poznań. Acta Sci Pol Silv Colendar Rat Ind Lignaria 9:51-69

Wrońska-Pilarek D, Stasik L (2003) The dendroflora of the "Debina" ecological land in Poznań. Sci Pap Agricul Univ Poznań, For 6:67-78

Zelený D, Schaffers AP (2012) Too good to be true: pitfalls of using mean Ellenberg indicator values in vegetation analyses. J Veg Sci 23:419 431. doi:10.1111/j.1654-1103.2011.01366.x

Zerbe S, Wirth P (2006) Non-indigenous plant species and their ecological range in central European pine (Pinus sylvestris L.) forests. Ann For Sci 63:189-203. doi:10.1051/forest:2005111

Żmudzka E (2012) Wieloletnie zmiany zasobów termicznych w okresie wegetacyjnym i aktywnego wzrostu roślin w Polsce. Woda-ŚrodObsz Wiej 12:377-389 